\title{
Effect of Short-Time Aging on the Pitting Corrosion Behavior of a Novel Lean Duplex Stainless Steel 2002
}

\author{
Tian-Yi Sun ${ }^{1} \cdot$ Yan-Jun Guo ${ }^{1} \cdot$ Yi-Ming Jiang ${ }^{1} \cdot$ Jin Li $^{1}$ \\ Received: 7 June 2018/Revised: 20 August 2018/Published online: 9 October 2018 \\ (C) The Chinese Society for Metals and Springer-Verlag GmbH Germany, part of Springer Nature 2018
}

\begin{abstract}
The effect of short-time aging in the temperature range between 400 and $1000{ }^{\circ} \mathrm{C}$ on the pitting corrosion behavior and mechanical property of a novel lean duplex stainless steel (LDSS) 2002 was investigated through the potentiostatic critical pitting temperature (CPT) tests and the Charpy impact tests. Both the pitting corrosion resistance and the toughness of aged specimens degraded due to the precipitation of detrimental secondary phases and the most significant reduction of CPT and impact energy emerged at $650{ }^{\circ} \mathrm{C}$ concurrently. The CPT of LDSS 2002 specimen aged at $650{ }^{\circ} \mathrm{C}$ decreased by $28{ }^{\circ} \mathrm{C}$, and the impact energy dropped from 69 to $29 \mathrm{~J} / \mathrm{cm}^{2}$ compared with the solution-annealed sample. Transmission electron microscopy characterization showed that the main precipitates in LDSS 2002 were $\mathrm{Cr}_{2} \mathrm{~N}$ and $M_{23} \mathrm{C}_{6}$ along the ferriteaustenite grain boundaries.
\end{abstract}

Keywords Lean duplex stainless steel · Aging $\cdot$ Pitting corrosion $\cdot$ Impact energy $\cdot$ Precipitates

\section{Introduction}

Duplex stainless steels are widely used in numerous industries, such as oil refining, food processing, pulp and paper, and pharmaceuticals because of their higher strength, better chloride stress corrosion cracking (SCC) resistance and better pitting corrosion resistance than austenite stainless steels [1]. There have been two main development routes for duplex stainless steels manufacturing [2]. During the 1980s, the high-alloyed duplex stainless steels were developed to satisfy the service requirements of more aggressive environments by balancing the chromium and nickel forming elements and adding more nitrogen $[3,4]$. On the other hand, lean duplex stainless steels (LDSSs) with lower chromium and molybdenum addition were developed in order to control the cost of production and save the natural resources [5]. Compared with traditional austenite grades, such as 304L and $316 \mathrm{~L}$, lean duplex stainless steels possess similar

Available online at http://link.springer.com/journal/40195

Jin $\mathrm{Li}$

corrosion@fudan.edu.cn

1 Department of Materials Science, Fudan University, Shanghai 200433, China pitting resistance but higher strength [6] and better SCC resistance against harsh environments containing chlorides [7]. Recently, a novel lean duplex stainless steel (LDSS) 2002 with a composition of $20.53 \mathrm{Cr}-3.45 \mathrm{Mn}-2.08 \mathrm{Ni}-$ $0.31 \mathrm{Mo}-0.17 \mathrm{~N}$ has been developed [8], which can achieve approximately 50\% elongation compared with the $30 \%$ elongation of the typical lean duplex stainless steel grade LDX 2101 by taking advantage of the transformation-induced plasticity (TRIP) effect.

The strain-induced martensite transformation mechanism that contributes to the excellent elongation of LDSS 2002 has already been explained by Guo et al. [8]. In addition, they also studied the effects of annealing temperature [9] and cooling rates in the temperature range of $1350-800{ }^{\circ} \mathrm{C}$ [10] on the pitting corrosion property of LDSS 2002. However, during the manufacturing and welding processes, the lean duplex stainless steels are bound to experience the temperature range of $400-1000{ }^{\circ} \mathrm{C}$, in which the volume fractions of ferrite phase and austenite phase may change and a myriad of harmful precipitates, such as intermetallic phases $(\sigma, \chi)$, carbides $\left(M_{23} \mathrm{C}_{6}\right)$, nitrides $\left(\mathrm{Cr}_{2} \mathrm{~N}\right)$ and secondary austenite $\left(\gamma_{2}\right)$, may form and affect both the mechanical and corrosion properties of the steels [11].

Deng et al. [12] first reported that the critical pitting temperature tests could be employed to evaluate the effect 
of short-time aging in the temperature range $450-1000{ }^{\circ} \mathrm{C}$ on the pitting corrosion resistance of duplex stainless steels DSS 2205. Not only is critical temperature test more sensitive to low amount of $\sigma$ phase precipitation than the traditional potentiodynamic polarization tests, but it can also help locate the initiation sites of pits in the duplex microstructures. Similarly, Zhang et al. [13] and Wei et al. [14] studied the change of pitting corrosion resistance and impact energy of the lean duplex stainless steel LDX 2101 when it was aged at $700{ }^{\circ} \mathrm{C}$ for different durations from 3 to $240 \mathrm{~min}$. It was suggested that the precipitation of $\mathrm{Cr}_{2} \mathrm{~N}$ caused the drop of CPT and impact energy [14]. More than that, Fang et al. [15] carried out isothermal aging treatment on LDX 2101 in the temperature range from 700 to $850{ }^{\circ} \mathrm{C}$ for different periods from 2 to $1440 \mathrm{~min}$, they found that the main precipitates were $\mathrm{Cr}_{2} \mathrm{~N}$-type nitrides and $M_{23} \mathrm{C}_{6}$ type carbides, and the impact energy of aged samples decreased by about $59 \%$ compared with as-annealed samples when $2 \%$ secondary phases formed during the aging process.

In this work, the effect of short-time aging on the corrosion behavior of LDSS 2002 has been examined systematically. The critical pitting temperature tests and the Charpy impact tests were employed to study the change of pitting corrosion resistance and mechanical properties of the aged LDSS 2002 specimens, respectively. Microstructure evolution and pit morphology were observed by optical microscopy (OM) and scanning electron microscopy (SEM), while the types of major precipitates were determined by transmission electron microscopy (TEM).

\section{Experimental}

\subsection{Sample Preparation}

The chemical composition of this newly developed LDSS 2002 is listed in Table 1. This alloy was smelted from raw materials in a vacuum furnace and then cast into a square ingot. After descaling, the ingot was forged into a 40-mmthick plate in the temperature range of $900-1200{ }^{\circ} \mathrm{C}$. After that, the plate was hot-rolled to $4 \mathrm{~mm}$ at $1200{ }^{\circ} \mathrm{C}$ and then cold-rolled to $1.5 \mathrm{~mm}$, followed by quenching in the water. The mole fractions of phases in LDSS 2002 calculated by Thermo-Calc software are presented in Fig. 1.

\subsection{Heat Treatment and the Charpy Impact Test}

All the samples were solution annealed at $1000{ }^{\circ} \mathrm{C}$ for $30 \mathrm{~min}$ to obtain the best mechanical and corrosion-resistant properties. In order to find out the effect of short-time aging on the pitting corrosion behavior and the mechanical properties of LDSS 2002, the samples were aged at $400{ }^{\circ} \mathrm{C}$, $500{ }^{\circ} \mathrm{C}, 600{ }^{\circ} \mathrm{C}, 650{ }^{\circ} \mathrm{C}, 700{ }^{\circ} \mathrm{C}, 750{ }^{\circ} \mathrm{C}, 800{ }^{\circ} \mathrm{C}, 850{ }^{\circ} \mathrm{C}$, $900{ }^{\circ} \mathrm{C}$ or $1000{ }^{\circ} \mathrm{C}$, respectively, for $10 \mathrm{~min}$, followed by water quenching. The Charpy impact test was performed by AHC-3000/2-AT impact test machine according to Metallic Materials-Charpy Pendulum Impact Test Method (GB/T229-2007) at room temperature [16]. The samples after heat treatment were processed into $10 \mathrm{~mm} \times 10 \mathrm{~mm} \times 55 \mathrm{~mm} \mathrm{~V}$-notched specimens, and the maximum impact energy was $290 \mathrm{~J}$.

\subsection{Electrochemical Measurements}

All the electrochemical measurements were performed on a CHI660D workstation (Shanghai Chenhua) in a threeelectrode cell with a saturated calomel electrode (SCE) as reference electrode and a thin platinum foil as counter electrode. The working electrode was specimen embedded in epoxy resin with exposing surface area of $1 \mathrm{~cm}^{2}$, which was pre-milled from 600 to 2000 grit with silicon carbide abrasive papers, polished by $1.5 \mu \mathrm{m}$ diamond pastes, rinsed in the ethanol and dried in the thermostat cabinet at $50{ }^{\circ} \mathrm{C}$.

Before the critical pitting temperature (CPT) test, highpurity nitrogen was bubbled through the solution in the cell to expel the oxygen for at least $30 \mathrm{~min}$. Referring to the ASTM G150-99 [17], the specimens were polarized at $250 \mathrm{mV}$ (SCE) constantly in $1 \mathrm{~mol} / \mathrm{L} \mathrm{NaCl}$ solution and the solution temperature was increased from $5{ }^{\circ} \mathrm{C}$ at the speed of $1{ }^{\circ} \mathrm{C} / \mathrm{min}$. When the current density increased sharply to $100 \mu \mathrm{A} / \mathrm{cm}^{2}$, the corresponding temperature was recorded as critical pitting temperature. All the CPT tests and Charpy impact tests were repeated at least three times to ensure the reliability of the data presented in this work.

\subsection{Microstructure Characterization}

Metallographic samples were electrochemically etched in $30 \mathrm{wt} \% \mathrm{KOH}$ solution at $2 \mathrm{~V}$ for $10 \mathrm{~s}$ to differentiate the ferrite phases from the austenite phases and etched in $10 \mathrm{wt} \%$ oxalic acid solution by applying 1 A direct current for $10 \mathrm{~s}$ to reveal the precipitation of carbides. The metallographic analysis was performed on a $4 \mathrm{XG}$ inverted
Table 1 Chemical composition (wt\%) of LDSS 2002

\begin{tabular}{lllllllllll}
\hline $\mathrm{C}$ & $\mathrm{Si}$ & $\mathrm{Mn}$ & $\mathrm{P}$ & $\mathrm{S}$ & $\mathrm{Cr}$ & $\mathrm{Ni}$ & $\mathrm{Mo}$ & $\mathrm{Cu}$ & $\mathrm{N}$ & $\mathrm{Fe}$ \\
\hline 0.031 & 0.32 & 3.45 & 0.01 & 0.004 & 20.53 & 2.08 & 0.31 & 0.34 & 0.17 & Bal. \\
\hline
\end{tabular}



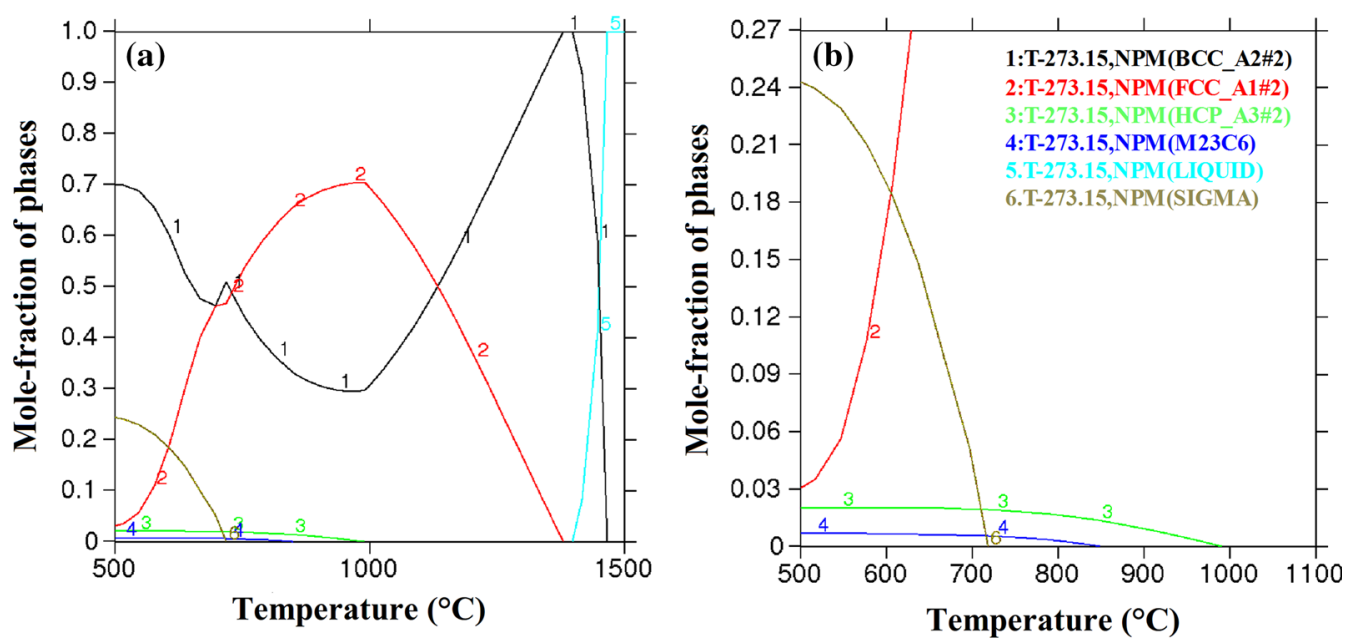

Fig. 1 Equilibrium mole fractions of phases in LDSS 2002 calculated by Thermo-Calc. a Equilibrium mole fractions of phases during $500-1500{ }^{\circ} \mathrm{C}$, b equilibrium mole fractions of precipitates during $500-1100{ }^{\circ} \mathrm{C}$

metallurgic microscope. The pit morphology was observed by a scanning electron microscope (SEM, Philips XL30 FEG). The characterization of precipitates was carried out by a transmission electron microscope (TEM, JEOL JEM $2100 \mathrm{~F}$ ) running at $200 \mathrm{kV}$, and the TEM samples were twin-jet electropolished in mixed solution of $10 \mathrm{vol} \%$ perchloric acid and 90 vol\% ethanol at $30 \mathrm{~V},-30^{\circ} \mathrm{C}$.

\section{Results}

\subsection{Effects of Aging on Pitting Corrosion and Impact Energy}

Figure 2 shows the CPT test curves of LDSS 2002 aged at different temperatures for $10 \mathrm{~min}$. The CPT values of

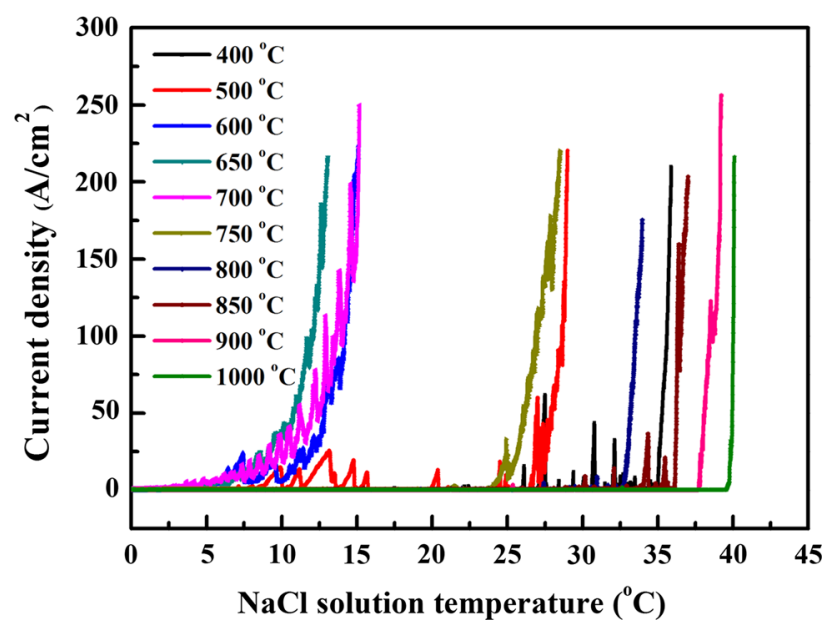

Fig. 2 Curves of current density to temperature for specimens aged at different temperatures for $10 \mathrm{~min}$ polarized at $250 \mathrm{mV}$ (SCE) in $1 \mathrm{~mol} / \mathrm{L} \mathrm{NaCl}$ solution specimens aged at $400{ }^{\circ} \mathrm{C}, 500{ }^{\circ} \mathrm{C}, 600{ }^{\circ} \mathrm{C}, 650{ }^{\circ} \mathrm{C}$, $700{ }^{\circ} \mathrm{C}, 750{ }^{\circ} \mathrm{C}, 800{ }^{\circ} \mathrm{C}, 850{ }^{\circ} \mathrm{C}, 900{ }^{\circ} \mathrm{C}$ or $1000{ }^{\circ} \mathrm{C}$ were $35.6{ }^{\circ} \mathrm{C}, 28.6{ }^{\circ} \mathrm{C}, 14.2{ }^{\circ} \mathrm{C}, 12{ }^{\circ} \mathrm{C}, 13.6{ }^{\circ} \mathrm{C}, 27{ }^{\circ} \mathrm{C}, 33.5^{\circ} \mathrm{C}$, $36.3{ }^{\circ} \mathrm{C}, 38.4{ }^{\circ} \mathrm{C}$ or $40^{\circ} \mathrm{C}$, respectively. For a typical CPT test curve, in the low-temperature range, the current density was below $1 \mu \mathrm{A} / \mathrm{cm}^{2}$, which meant that the surface of the specimen was passive. With increasing solution temperature, some small current transients appear in the curve, indicating the formation and repassivation of metastable pits on the surface of the test specimen $[18,19]$. If a stable pit was formed on the surface of the aged LDSS 2002 specimen, the current density would increase dramatically and the exact temperature when the current density approached $100 \mu \mathrm{A} / \mathrm{cm}^{2}$ was recorded as the CPT [17].

The CPT of specimens aged at different temperatures for 10 min decreased from 400 to $650{ }^{\circ} \mathrm{C}$ and reached the minimum at $650{ }^{\circ} \mathrm{C}$. With the increase of the aging temperature from 650 to $1000{ }^{\circ} \mathrm{C}$, the CPT rose back. The trend of impact energy of aged specimens versus aging temperature changed simultaneously with the CPT values (Fig. 3). It was possible that the precipitation of harmful precipitates caused the degradation of pitting corrosion resistance and the mechanical property of LDSS 2002 [12-14].

\subsection{Microstructure Evolution}

According to Fig. 1a, the main phases in LDSS 2002 are the ferrite phase and the austenite phase. Moreover, there are detrimental secondary phases such as $M_{23} \mathrm{C}_{6}(M=\mathrm{Cr}$, Mo), $\mathrm{Cr}_{2} \mathrm{~N}$ and $\sigma$ phase precipitating in the range of $500-980{ }^{\circ} \mathrm{C}$ (Fig. 1b). It is known that the exceptional mechanical and corrosion resistance property of duplex stainless steel arises from its balanced volume fraction ratio 


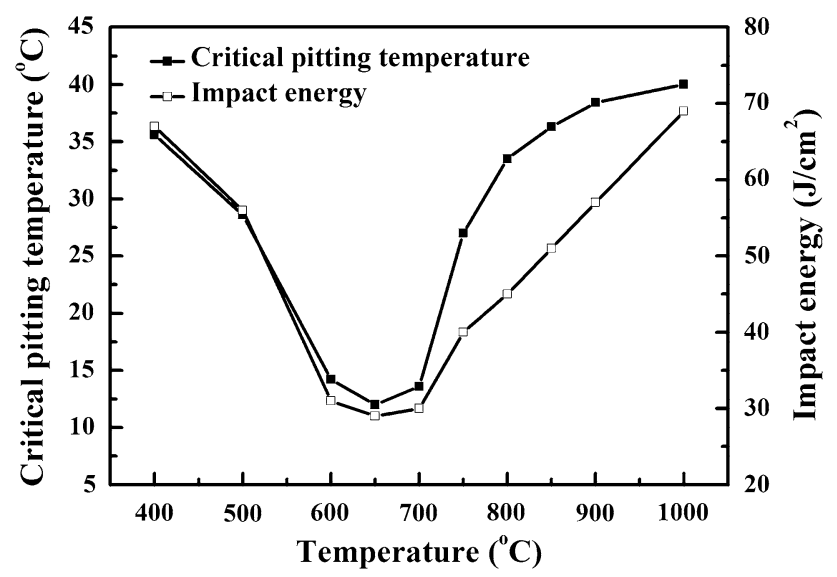

Fig. 3 CPT and impact energy of LDSS 2002 aged at different temperatures for $10 \mathrm{~min}$

of the ferrite phase to the austenite phase [1,2]. Figure 4 shows the microstructure evolution of LDSS 2002 specimens after different aging treatments. It can be seen from Fig. 4 that the light gray island-shaped austenite phases were almost uniformly distributed in the dark ferrite matrix. When the aging temperature increased from 400 to $800{ }^{\circ} \mathrm{C}$, the volume fraction of austenite increased, while the volume fraction of ferrite decreased due to the decomposition of ferrite phase, in which the ferrite phase $(\alpha)$ transformed into secondary austenite $\left(\gamma_{2}\right)$ and other secondary phases [20]. However, in the temperature range of $800-900{ }^{\circ} \mathrm{C}$, the amount of austenite decreased and the amount of ferrite increased with the rise of the aging temperature. It indicated a phase transformation from the austenite phase into the ferrite phase, which was a diffusion-controlled transformation determined by equilibrium diagram [21]. Besides, there was another notable change in the morphology of the austenite phase. At low temperature where the thermal activation was not strong enough, the austenite phase was mostly plateau-structured primary austenite $\left(\gamma_{1}\right)$, which was also referred to as partially transformed austenite (PTA) [22]. At high temperature, the secondary austenite phases $\left(\gamma_{2}\right)$ with different morphologies started to form. According to the literature, Widmanstätten austenite (WA) can grow at the boundaries between allotriomorphic austenite and ferrite in the form of parallel laths or nucleate directly from the prior ferrite boundaries, which are not covered by allotriomorphic austenite [23]. In Fig. 4d-f, round-shaped PTA reduced and platelike WA kept increasing. At higher temperature, there was enough activation energy for lattice diffusion. This long-range diffusion and stability of nitrides made the nucleation and growth of intragranular austenite (IGA) possible [22]. In Fig. $4 \mathrm{~g}-\mathrm{i}$, there was almost no round-
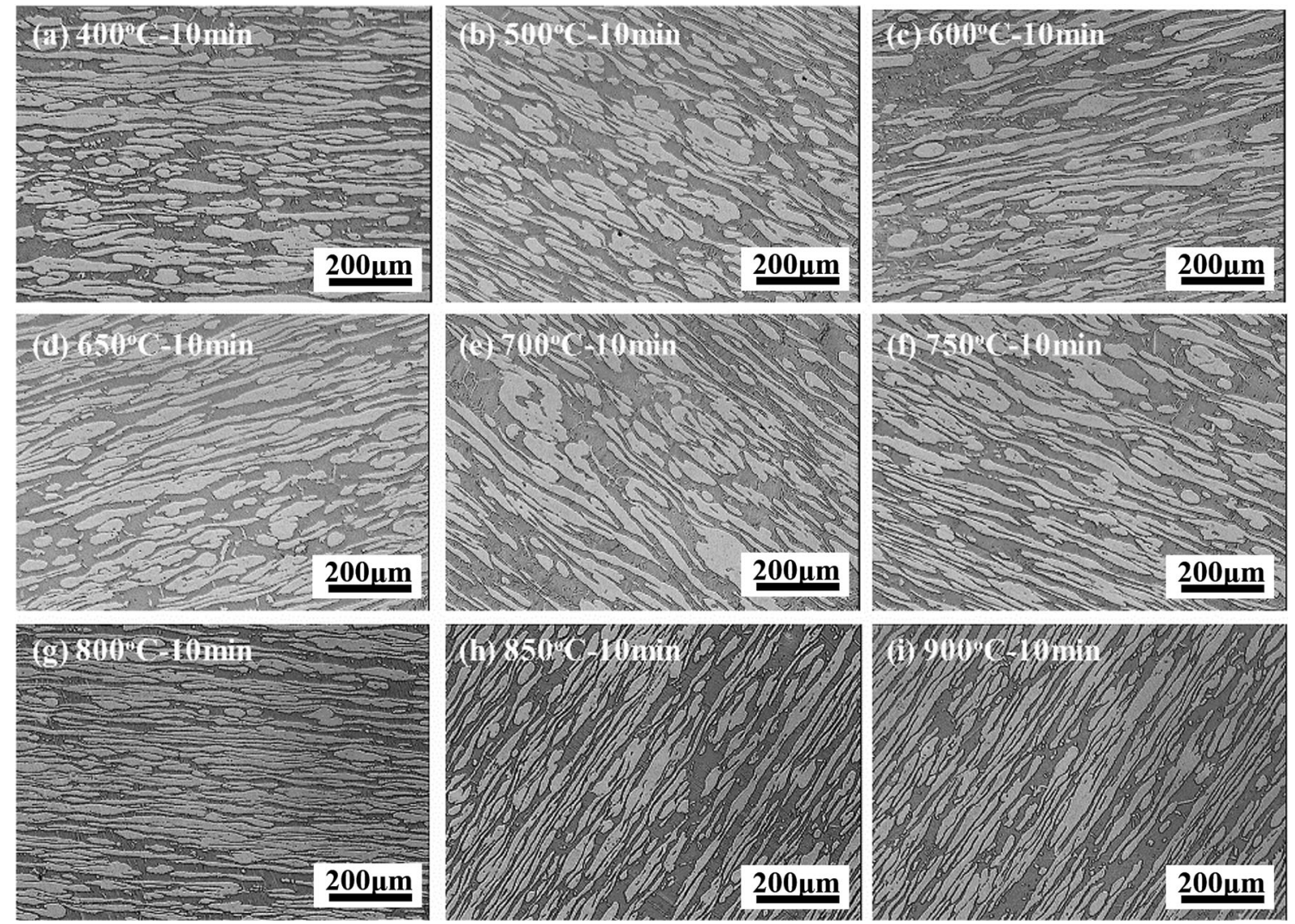

Fig. 4 Optical micrographs of LDSS 2002 aged at different temperatures for 10 min (etching in $30 \mathrm{wt} \% \mathrm{KOH}$ ) 
shaped PTA and the rodlike IGA was thinner than the WA in Fig. 4d-f, because the lattice diffusion was much slower than grain boundary diffusion and the IGA was less grown compared with WA $[22,23]$.

Figure 5 shows the optical micrographs of aged LDSS 2002 specimens after etching in oxalic acid to reveal the carbides precipitation [24, 25]. Evident ditches along the grain boundaries could be seen in samples aged at $650{ }^{\circ} \mathrm{C}$, $700{ }^{\circ} \mathrm{C}$ and $750{ }^{\circ} \mathrm{C}$ (Fig. 5d-f) and the depth and amount of ditches increased when the aging temperature decreased from 750 to $650{ }^{\circ} \mathrm{C}$. However, only mild ditches could be found in samples aged below $650{ }^{\circ} \mathrm{C}$ or above $750{ }^{\circ} \mathrm{C}$ (Fig. 5a-c, g-i). Although oxalic acid etching failed to exhibit the difference between the ferrite phase and the austenite phase, it confirmed the precipitation of carbides at the grain boundaries in the aged LDSS 2002 specimens.

It is quite difficult to find and identify the precipitates in the short-time (10 $\mathrm{min}$ ) aged LDSS 2002 specimens due to the small size and scarce amount of the precipitates. The TEM characterization was performed for the LDSS 2002 specimens aged at $650{ }^{\circ} \mathrm{C}$ for $0.5 \mathrm{~h}$. As is shown in Fig. 6a, a large rodlike $\mathrm{Cr}_{2} \mathrm{~N}$ precipitate of about 700-nm length and 150-nm thickness was found in the region of ferrite grain. Zhang et al. [14] reported an average length of 200-1000 nm and a thickness of 50-100 nm, when they examined the $\mathrm{Cr}_{2} \mathrm{~N}$ precipitate in the ferrite grains of the LDX 2101 aged at $700{ }^{\circ} \mathrm{C}$ for $30 \mathrm{~min}$. Other related researches in duplex stainless steel weldments indicate that $\mathrm{Cr}_{2} \mathrm{~N}$ initiates at the ferrite-austenite boundaries and then grows into the ferrite phase [26, 27]. In the white dashedline circle in Fig. $6 \mathrm{a}$, the $\mathrm{Cr}_{2} \mathrm{~N}$ precipitates of relatively smaller size were found along the interface between the ferrite and the secondary austenite $\left(\gamma_{2}\right)$ because the high nitrogen solubility in $\gamma_{2}$ phase suppressed the growth of the $\mathrm{Cr}_{2} \mathrm{~N}$ precipitates at the interface $[23,28]$. Figure $6 \mathrm{c}$ shows that a triangular $M_{23} \mathrm{C}_{6}$ carbide of mean equivalent diameter approximately $100 \mathrm{~nm}$ precipitated at the ferriteaustenite boundary. Similarly, Maetz et al. [29] found that in LDX 2101 the triangular $M_{23} \mathrm{C}_{6}$ carbides whose biggest mean equivalent diameters are also $\sim 100 \mathrm{~nm}$ only precipitate along the ferrite-austenite boundaries and stop growing after aging at $690{ }^{\circ} \mathrm{C}$ for more than $15 \mathrm{~min}$.

\subsection{Pit morphology}

The pits distribution on the surfaces of the specimens after CPT tests has exhibited certain regularity (Fig. 7). At $500{ }^{\circ} \mathrm{C}$, stable pits with lacy cover preferentially located in the ferrite phase, indicating that the ferrite phase was more susceptible to pitting corrosion under this aging condition.
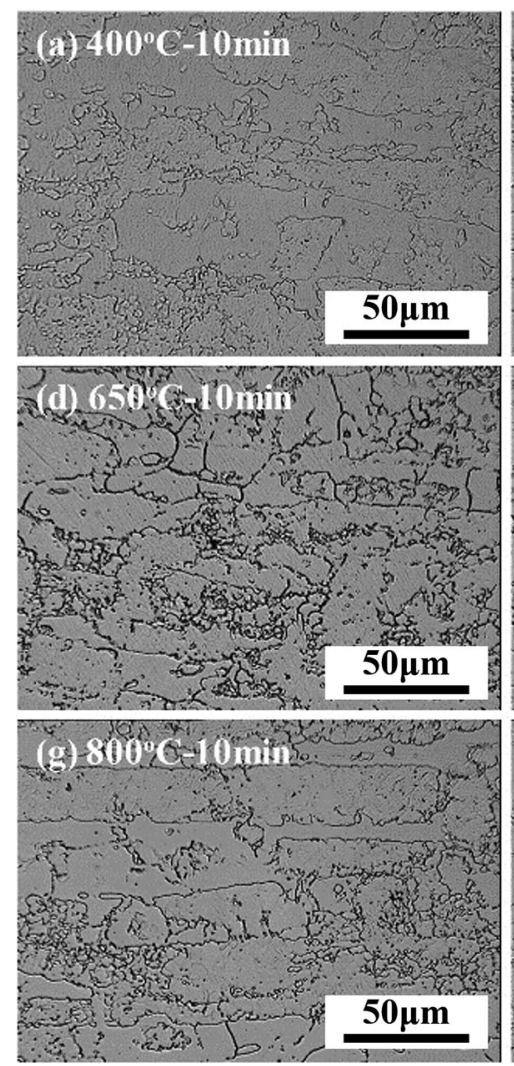
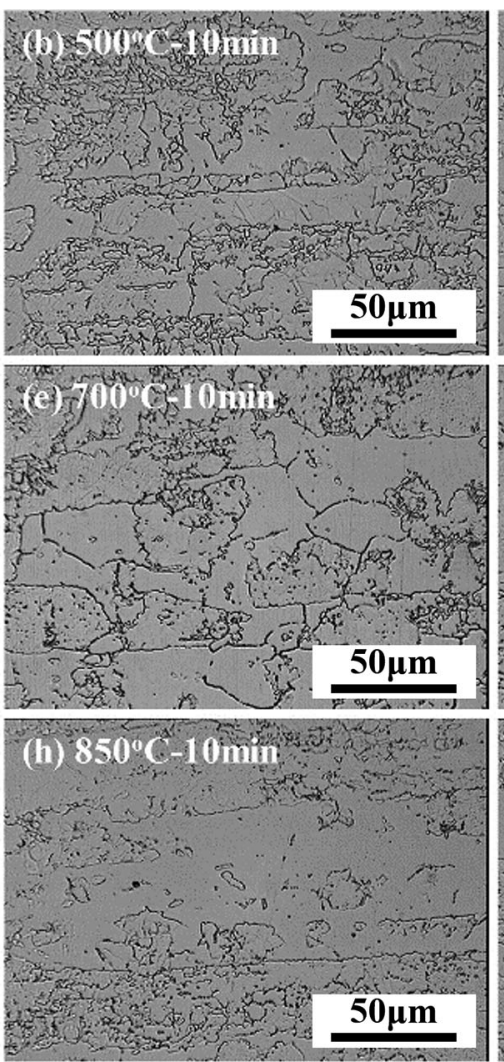
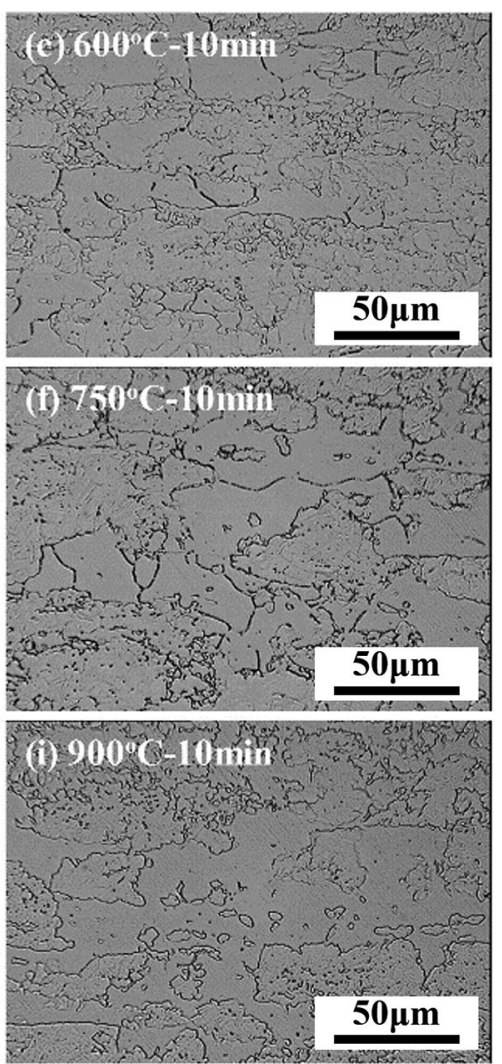

Fig. 5 Optical micrographs of LDSS 2002 aged at different temperatures for 10 min (etching in 10 wt\% oxalic acid) 

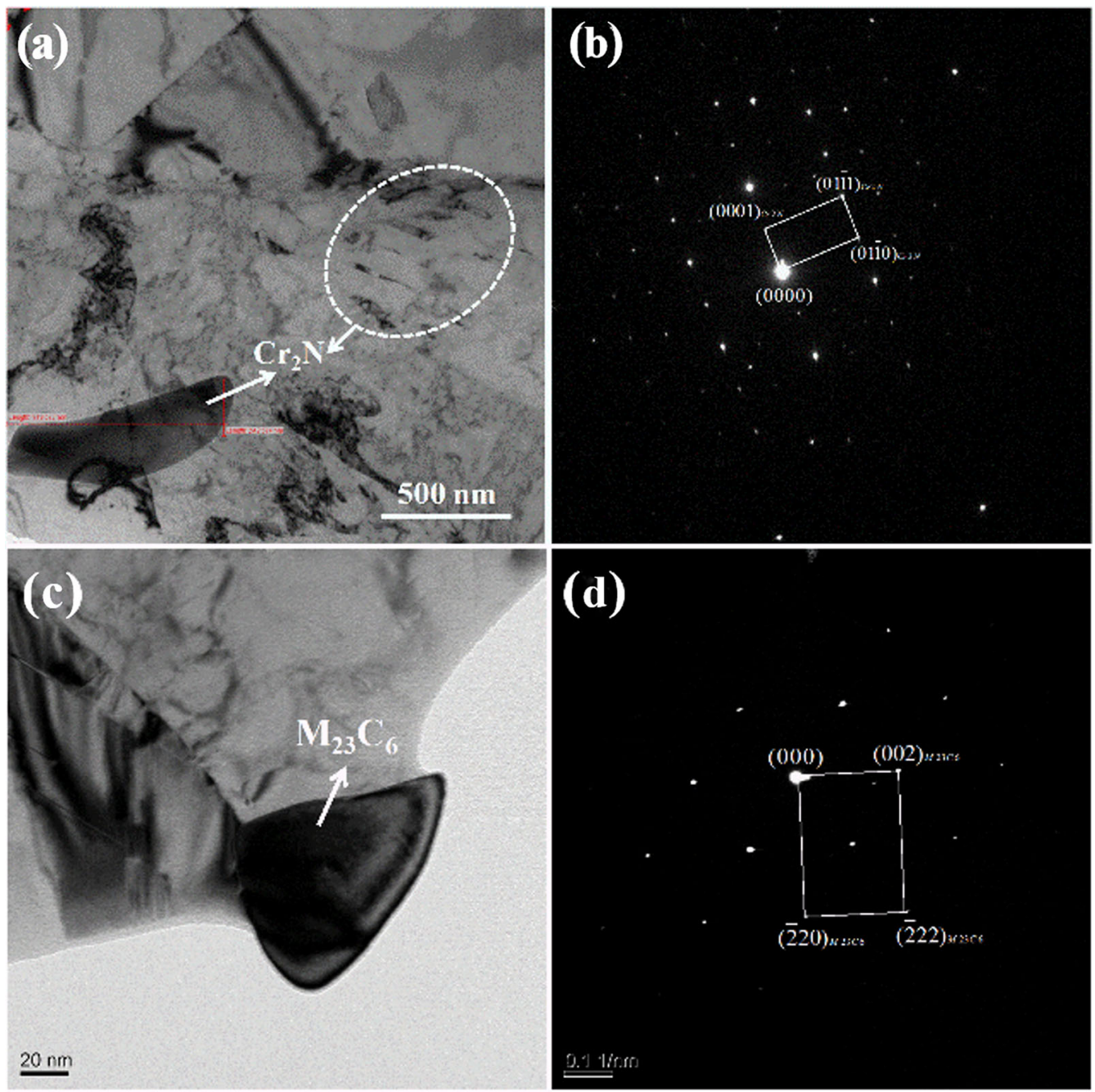

Fig. 6 TEM images of $\mathrm{Cr}_{2} \mathrm{~N}$ and $M_{23} \mathrm{C}_{6}$ of LDSS 2002 aged at $650{ }^{\circ} \mathrm{C}$ for $0.5 \mathrm{~h}$. a A bright field image of $\mathrm{Cr}_{2} \mathrm{~N}$, b corresponding selected area electron diffraction (SAED) pattern of $\mathrm{Cr}_{2} \mathrm{~N}$, $\mathbf{c}$ a bright field image of $M_{23} \mathrm{C}_{6}, \mathbf{d}$ corresponding SAED pattern of $M_{23} \mathrm{C}_{6}$

In the temperature range of $600-750{ }^{\circ} \mathrm{C}$, metastable pits nucleated along the ferrite-austenite boundaries and grew into the ferrite phase during $600-650{ }^{\circ} \mathrm{C}$ because the chromium-rich precipitates precipitated along the ferriteaustenite boundaries, which formed local chromium-depleted zones near the boundaries and rendered these spots more vulnerable to pitting corrosion attacks [13, 30].

At $800{ }^{\circ} \mathrm{C}$, the preferential pitting sites transferred into the austenite phase, suggesting that the austenite phase was now easier to suffer from pitting corrosion than the ferrite phase. It could be understood that the volume fraction of the austenite phase reached the maximum at $800{ }^{\circ} \mathrm{C}$ (Fig. 4), the concentration of corrosion-resistant alloy elements $(\mathrm{Cr}, \mathrm{Mo}, \mathrm{N})$ was diluted, and the pitting corrosion resistance of the austenite phase dropped.

From 850 to $1000{ }^{\circ} \mathrm{C}$, the stable pits equally propagated into the ferrite phase and the austenite phase, because the pitting corrosion resistance of the two phases was almost equal $[9,21,31]$.

\section{Discussion}

Based on the distribution regularity of the pitting sites, the curves of CPT and impact energy of short-time aged specimens versus the aging temperature can be well explained. When the specimens were aged between 400 and $500{ }^{\circ} \mathrm{C}$, the mobility of chromium was not enough for chromium-rich carbides or nitrides to precipitate. Instead, the ferrite phase had the inclination to transform into an extremely fine and chromium-rich $\alpha^{\prime}$ phase. The precipitation of $\alpha^{\prime}$ phase formed chromium-depleted zones in the ferrite phase, which was the reason that the pits nucleated preferentially in the ferrite phase and the CPT dropped 5-10 ${ }^{\circ} \mathrm{C}$ compared with solution-annealed specimen [32]. 

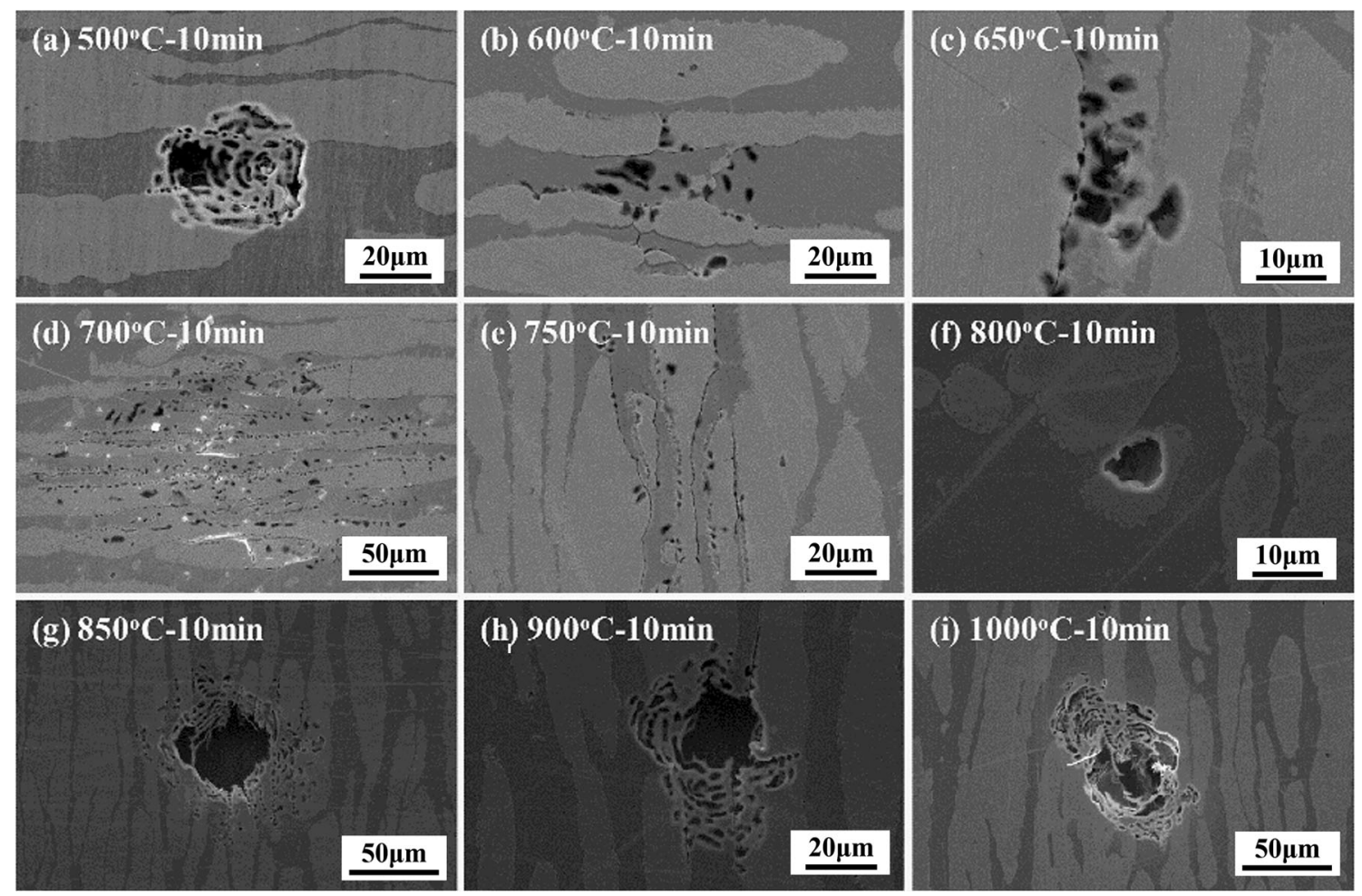

Fig. 7 SEM micrographs of pit morphologies after CPT test on the surface of LDSS specimens aged at different temperatures for 10 min

Sahu et al. [33, 34] observed that the impact energy of DSS DIN W Nr. 1.4462 decreased from 260 to $8 \mathrm{~J}$ after aging at $475{ }^{\circ} \mathrm{C}$ for $100 \mathrm{~h}$, and Grobner [35] reported that in the temperature range of $371-482{ }^{\circ} \mathrm{C}$ iron-chromium alloy with 18 at.\% chromium embrittled in $2 \mathrm{~h}$. Besides, Weng et al. found that when DSS 2205 was aged at 450, 475 and $500{ }^{\circ} \mathrm{C}$, the toughness decreased with the increase of aging time, a significant decrease in toughness occurred in the initial stage, and then an accelerated drop happened. The impact energy of specimens aged at $475{ }^{\circ} \mathrm{C}$ for $8 \mathrm{~h}$ fell to less than half $(150 \mathrm{~J})$ of the annealed ones [36]. In this work, the impact energy of LDSS 2002 dropped from 75 (annealing state) to $56 \mathrm{~J} / \mathrm{cm}^{2}$ after aging at $500{ }^{\circ} \mathrm{C}$ for $10 \mathrm{~min}$.

In the temperature range of $600-750{ }^{\circ} \mathrm{C}$, the ferrite phase $(\alpha)$ was decomposed into secondary austenite $\left(\gamma_{2}\right)$ and other secondary phases such as carbides $\left(M_{23} \mathrm{C}_{6}\right)$ and nitrides $\left(\mathrm{Cr}_{2} \mathrm{~N}\right)$ [14, 20, 37, 38]. According to the results of oxalic acid etching experiments and TEM characterization, $M_{23} \mathrm{C}_{6}$ precipitated along the ferrite-austenite grain boundaries, leading to the formation of chromium-depleted zones near the grain boundaries, which were more susceptible to pitting corrosion and led to a large decrease in CPT (about $25^{\circ} \mathrm{C}$ ). Especially, the amount of carbides precipitation reached its maximum at $650{ }^{\circ} \mathrm{C}$, and the CPT decreased by $28{ }^{\circ} \mathrm{C}$, which was $30 \%$ of the annealed specimen. The pitting corrosion resistance was the worst, and the pits preferentially initiated along the ferriteaustenite boundaries [30]. Besides, the carbides also deteriorated the toughness of LDSS 2002 as one of the brittle phases [39]. Therefore, the impact energy also decreased by $40 \mathrm{~J} / \mathrm{cm}^{2}$ and achieved its minimum of $29 \mathrm{~J} / \mathrm{cm}^{2}$, which was $42 \%$ of that for as-annealed specimens. In the previous work, when lean duplex stainless steel LDX 2101 was aged at $700{ }^{\circ} \mathrm{C}$ for $15 \mathrm{~min}$, the CPT decreased to $44 \%$ of the annealed specimen and the impact energy dropped about $68 \%$ by a decrease of $38 \mathrm{~J} \mathrm{[13].} \mathrm{In} \mathrm{another} \mathrm{research,} \mathrm{the}$ room temperature impact energy of aged LDX 2101 dropped obviously after $3 \mathrm{~min}$ and was halved after $10 \mathrm{~min}$. After $30 \mathrm{~min}$, the impact energy was $37 \mathrm{~J}$, only $34 \%$ of the as-annealed specimens [14]. The precipitation of $\mathrm{Cr}_{2} \mathrm{~N}$ along the ferrite-austenite boundaries and the ferrite grain boundaries was confirmed as the primary reason for the decrease in CPT and impact energy [13, 14]. It is reasonable to suggest that there were also $\mathrm{Cr}_{2} \mathrm{~N}$ precipitates in the LDSS 2002 specimens when they were aged in the temperature range of $600-750{ }^{\circ} \mathrm{C}$ due to their similar nitrogen volume fractions. In addition, the TEM characterization of the LDSS 2002 specimens aged at $650{ }^{\circ} \mathrm{C}$ for $0.5 \mathrm{~h}$ also identifies the existence of $\mathrm{Cr}_{2} \mathrm{~N}$ precipitates along with $M_{23} \mathrm{C}_{6}$ (Fig. 6). The precipitation of $M_{23} \mathrm{C}_{6}$ and $\mathrm{Cr}_{2} \mathrm{~N}$ depleted the adjacent chromium and caused both the large decrease in CPT and impact energy of short-time aged LDSS 2002 specimens. 
When the duplex stainless steels were aged at 800-900 ${ }^{\circ} \mathrm{C}$, the intermetallic phases such as $\sigma$ phase and $\chi$ phase were likely to precipitate $[12,20,40]$. However, for lean duplex stainless steels, the kinetics of $\sigma$ phase and $\chi$ phase precipitation is much slower than that of standard duplex stainless steel grade like DSS 2205 due to their lower chromium and molybdenum contents. Only prolonged aging time of hours could increase the volume fraction of $\sigma$ phase $[15,37]$. It could be seen from Fig. 5 that the amount of carbides precipitates decreased with the increase of the aging temperature in the range of 800-900 ${ }^{\circ} \mathrm{C}$, which was due to the thermodynamic instability of $M_{23} \mathrm{C}_{6}$ and $\mathrm{Cr}_{2} \mathrm{~N}$ in this temperature range [32]. Therefore, the CPT and impact energy began to rise back. Also, at elevated temperatures, long-distance diffusion was so enhanced that the chromium inside the austenite grains could arrive at the ferrite-austenite boundaries and replenish the chromium-depleted zones, which helped to increase the CPT value and explained the preferential location of pits in the austenite phase of the LDSS 2002 specimens aged at $800{ }^{\circ} \mathrm{C}$.

In summary, it could be concluded that the precipitation of $M_{23} \mathrm{C}_{6}$ and $\mathrm{Cr}_{2} \mathrm{~N}$ along the ferrite-austenite boundaries played an important role in the change of CPT and impact energy of the short-time aged LDSS 2002 specimens.

\section{Conclusions}

A novel lean duplex stainless steel LDSS 2002 with lower alloy element contents but better corrosion resistance and mechanical properties than the classical lean duplex stainless steel grade LDX 2101 has been studied. In order to provide scientific guidance and data support for the manufacturing and welding processes of LDSS 2002 in industrial application, the effect of short-time aging on the CPT and impact energy of LDSS 2002 has been systematically examined. Based on the data conveyed above, the major conclusions are as follows:

1. The CPT values and impact energy of LDSS 2002 first decreased and then increased with the aging temperature increasing from 400 to $1000{ }^{\circ} \mathrm{C}$. Both the CPT and impact energy reached the minimum value when LDSS 2002 specimens were aged at $650{ }^{\circ} \mathrm{C}$ for $10 \mathrm{~min}$.

2. Although the morphology of austenite phase experienced a noticeable change, the volume fraction ratio of ferrite to austenite almost retained balanced in the aged specimens. The chief reason for the degradation of pitting corrosion resistance and toughness of shorttime aged LDSS 2002 specimens was the precipitation of nitrides and carbides along the ferrite-austenite boundaries.

3. The TEM characterization confirmed that the main precipitates in LDSS 2002 specimens aged at $650{ }^{\circ} \mathrm{C}$ for $0.5 \mathrm{~h}$ were $\mathrm{Cr}_{2} \mathrm{~N}$ and $M_{23} \mathrm{C}_{6}$ along the ferriteaustenite grain boundaries.

Acknowledgements The authors acknowledge the financial support from the National Natural Science Foundation of China (Grant Nos. 51671059 and 51501041).

\section{References}

[1] R.N. Gunn, Duplex Stainless Steels: Microstructure, Properties and Applications (Woodhead Publishing, Cambridge, 1997)

[2] J. Charles, Rev. Métall. Int. J. Metall. 105, 155 (2008)

[3] C.T. Sims, N.S. Stoloff, W.C. Hagel, Superalloys II (Wiley, New York, 1987)

[4] J.O. Nilsson, Mater. Sci. Technol. 8, 685 (1992)

[5] M. Liljas, P. Johansson, H. Liu, C.A. Olsson, Steel Res. Int. 79, 466 (2008)

[6] H.M. Cobb, The History of Stainless Steel (ASM International, Materials Park, 2010)

[7] I. Alvarez-Armas, Recent Pat. Mech. Eng. 1, 51 (2008)

[8] Y. Guo, J. Hu, Y. Jiang, J. Li, Int. J. Electrochem. Sci. 11, 4812 (2016)

[9] Y. Guo, J. Hu, J. Li, L. Jiang, T. Liu, Y. Wu, Materials 7, 6604 (2014)

[10] Y. Guo, T. Sun, J. Hu, Y. Jiang, L. Jiang, J. Li, J. Alloys Compd. 658, 1031 (2016)

[11] G.F. Vander Voort, Atlas of Time-Temperature Diagrams for Irons and Steels (ASM international, Materials Park, 1991)

[12] B. Deng, Z. Wang, Y. Jiang, T. Sun, J. Xu, J. Li, Corros. Sci. 51, $2969(2009)$

[13] L. Zhang, Y. Jiang, B. Deng, W. Zhang, J. Xu, J. Li, Mater. Charact. 60, 1522 (2009)

[14] W. Zhang, L. Jiang, J. Hu, H. Song, Mater. Charact. 60, 50 (2009)

[15] W. Xue, H. Song, ISIJ Int. 50, 286 (2010)

[16] W. Zheng, GB/T 229-2007: Translated English of Chinese Standard. (GBT 229-2007, GB/T229-2007, GBT229-2007): Metallic Materials-Charpy Pendulum Impact Test Method (2016)

[17] L. Wegrelius, C. Sun, Standard Test Method for Electrochemical Critical Pitting Temperature Testing of Stainless Steels (ASTM International, Materials Park, 2010)

[18] G.S. Frankel, L. Stockert, F. Hunkeler, H. Boehni, Corrosion 43, 429 (1987)

[19] M.H. Moayed, R.C. Newman, Corros. Sci. 48, 1004 (2006)

[20] Y.S. Ahn, J.P. Kang, Mater. Sci. Technol. 16, 382 (2000)

[21] M. Yousefieh, M. Shamanian, A. Saatchi, J. Mater. Eng. Perform. 20, 1678 (2011)

[22] A. Eghlimi, M. Shamanian, K. Raeissi, Surf. Coat. Technol. 244, 45 (2014)

[23] T. Chen, J. Yang, Mater. Sci. Eng. A 338, 166 (2002)

[24] G. Herbsleb, P. Schwaab, Werkst. Korros. 37, 24 (1986)

[25] H. Kokawa, M. Shimada, Y.S. Sato, JOM 52, 34 (2000)

[26] H. Matsunaga, Y.S. Sato, H. Kokawa, T. Kuwana, Sci. Technol. Weld. Join. 3, 225 (1998)

[27] D. Sundararaman, P. Shankar, V.S. Raghunathan, Metall. Mater. Trans. A 27, 1175 (1996) 
[28] A.J. Ramirez, J.C. Lippold, S.D. Brandi, Metall. Mater. Trans. A 34, 1575 (2003)

[29] J.Y. Maetz, T. Douillard, S. Cazottes, C. Verdu, X. Kléber, Micron 84, 43 (2016)

[30] J. Li, G. Li, W. Liang, P. Han, H. Wang, J. Mater. Eng. Perform. 26, 4533 (2017)

[31] Z. Zhang, H. Zhao, H. Zhang, Z. Yu, J. Hu, L. He, J. Li, Corros. Sci. 93, 120 (2015)

[32] B.F. Weiss, R. Stickler, Metall. Trans. 3, 851 (1972)

[33] J.K. Sahu, Dissertation, University of Siegen, Germany, 2008
[34] J.K. Sahu, U. Krupp, R.N. Ghosh, H.J. Christ, Mater. Sci. Eng. A 508, 1 (2009)

[35] P.J. Grobner, Metall. Trans. 4, 251 (1973)

[36] K. Weng, H. Chen, J. Yang, Mater. Sci. Eng. A 379, 119 (2004)

[37] K. Chan, S. Tjong, Materials 7, 5268 (2014)

[38] R. Badji, M. Bouabdallah, B. Bacroix, C. Kahloun, B. Belkessa, H. Maza, Mater. Charact. 59, 447 (2008)

[39] K. Guan, X. Xu, H. Xu, Z. Wang, Nucl. Eng. Des. 235, 2485 (2005)

[40] B. Deng, Z. Wang, Y. Jiang, H. Wang, J. Gao, J. Li, Electrochim. Acta 54, 2790 (2009) 